\title{
PENGARUH PENGETAHUAN DAN MOTIVASI KERJA DOKTER SPESIALIS TERHADAP PENGISIAN REKAM MEDIS RAWAT INAP DI RUMAH SAKIT SANTA ELISABETH MEDAN
}

\author{
Anthonyus \\ Dosen Prodi Sarjana Terapan Manajemen Informasi Kesehatan STIKes Santa \\ Elisabeth Medan,
}

\begin{abstract}
Background: Medical Record is a collection of data and information on patients related to administration, medical clinical processes and medical support, quality management and outcome of those processes, which are documented and stored systematically and safely to be used by parties Entitled and concerned..

Aim: The purpose of this study was to analyze the influence of the knowledge and motivation of the specialist's work on the filling of the medical record in the hospital ward of Santa Elisabeth Hospital.

Method: Type of research using explanatory research with associative approach. Population is all the specialist doctors who become Doctors in Patient Responsibility inpatient at Santa Elisabeth Hospital as many as 50 people, while the sample of research as many as 50 people. Data collection was done by giving questionnaires and observation sheet of medical record. Analysis of data with Chi Square and multiple logistic regression.

Results: The results showed that: 1) The knowledge of specialist physicians influenced the filling of hospitalized medical records at Santa Elisabeth Hospital Medan. This is indicated by the value of $p=0.030$, the value of $\exp (B) 6,837.2)$ Working motivation of specialist doctors influential on filling in medical records inpatient Hospital Santa Elisabeth Medan. This is indicated by the value of $p=0.005$, the value of exp (B) 6,635. 3).

Conclusion: There is a positive and significant influence between the knowledge and motivation of the specialist's work on the filling of the hospitalization records of Santa Elisabeth Hospital in Medan..
\end{abstract}

Keywords: Knowledge, Motivation, Medical Record, Hospital Santa Elisabeth

\begin{abstract}
ABSTRAK
Latar Belakang: Rekam Medis merupakan himpunan data dan informasi tentang pasien yang terkait dengan administrasi, proses-proses klinis medis dan penunjang medis, manajemen mutu serta out come dari proses-proses itu, yang didokumentasikan dan disimpan secara sistematis dan aman. Berdasarkan fenomena data penelitian didapatkan rendahnya tingkat kesadaran dokter spesialis dalam pengisian rekam medis rawat inap di Rumah Sakit Santa Elisabeth Medan.
\end{abstract}


Tujuan : Tujuan penelitian ini adalah untuk menganalisis pengaruh pengetahuan dan motivasi kerja dokter spesialis terhadap pengisian rekam medis di ruang rawat inap Rumah Sakit Santa Elisabeth.

Metode: Jenis penelitian ini adalah eksplanatory dengan pendekatan asosiatif. Populasi adalah seluruh tenaga dokter spesialis yang menjadi Dokter Penanggung Jawab Pasien (DPJP) rawat inap di Rumah Sakit Santa Elisabeth sebanyak 50 orang. Pengumpulan data dilakukan dengan pemberian kuesioner dan lembar observasi rekam medis. Analisa data dengan Chi Square dan regresi logistik berganda.

Hasil: Hasil penelitian menunjukkan bahwa: 1)Pengetahuan dokter spesialis berpengaruh terhadap pengisian rekam medis rawat inap Rumah Sakit Santa Elisabeth Medan. Hal ini ditunjukkan dengan nilai $\mathrm{p}=0,030$, nilai exp (B) 6,837. 2)Motivasi kerja dokter spesialis berpengaruh terhadap pengisian rekam medis rawat inap Rumah Sakit Santa Elisabeth Medan. Hal ini ditunjukkan dengan nilai p=0,005, nilai exp (B) 6,635. 3).

Simpulan: Terdapat pengaruh yang positif dan signifikan antara pengetahuan dan motivasi kerja dokter spesialis terhadap pengisian rekam medis rawat inap Rumah Sakit Santa Elisabeth Medan.

\section{Kata kunci: Pengetahuan, Motivasi, Rekam Medis, Rumah Sakit Santa Elisabeth}

\section{PENDAHULUAN}

Rumah sakit merupakan salah satu sarana kesehatan dan tempat penyelenggaraan upaya kesehatan serta suatu organisasi yang selalu berinteraksi dengan lingkungannya untuk mencapai suatu keseimbangan yang dinamis dan mempunyai fungsi utama melayani masyarakat yang membutuhkan pelayanan kesehatan. Upaya kesehatan adalah setiap kegiatan untuk memelihara dan meningkatkan kesehatan yang optimal bagi masyarakat. Upaya kesehatan diselenggarakan dengan pendekatan peningkatan kesehatan (promotif), pencegahan penyakit (preventif), penyembuhan penyakit (kuratif) dan pemulihan (rehabilitatif) yang dilaksanakan secara menyeluruh, terpadu dan berkesinambungan.

Tenaga dokter spesialis mempunyai kedudukan penting dalam menghasilkan kualitas pelayanan kesehatan di rumah sakit, karena pelayanan yang diberikannya berdasarkan pendekatan bio-psiko-sosial-spiritual dan dilaksanakan selama 24 jam secara berkesinambungan. Berkaitan dengan kedudukan tenaga dokter spesialis dalam menghasilkan kualitas pelayanan kesehatan di rumah sakit maka diperlukan upaya perbaikan mutu dan menjaga mutu pelayanan, termasuk kelengkapan pengisian rekam medis.

Rekam Medis merupakan himpunan data dan informasi tentang pasien yang terkait dengan administrasi, proses-proses klinis medis dan penunjang medis, manajemen mutu serta out come dari proses-proses itu, yang didokumentasikan dan disimpan secara sistematis dan aman untuk dapat digunakan oleh pihak-pihak yang berhak dan berkepentingan.

Rumah Sakit Santa Elisabeth adalah rumah sakit kelas B dengan visi: "Menjadi tanda kehadiran Allah di tengah dunia dengan membuka tangan dan hati untuk memberikan pelayanan kasih yang menyembuhkan orang-orang sakit dan menderita sesuai dengan tuntutan zaman". RS Santa Elisabeth Medan adalah rumah sakit swasta yang mempunyai pelayanan Jaminan Kesehatan Masyarakat. 
Sesuai dengan visi tersebut diatas, pengisian rekam medis secara lengkap dan akurat merupakan komitmen di Rumah Sakit Santa Elisabeth sesuai dengan prosedur tetap (protap). Dalam protap, seluruh item yang tercantum dalam lembaran rekam medis harus harus diisi dengan lengkap dan pengembalian berkas rekam medis harus tepat waktu.

Sesuai dengan Peraturan Menteri Kesehatan Republik Indonesia nomor 269 tahun 2008 tentang rekam medis dalam pasal 3 menyebutkan butir-butir minimal yang harus dimuat untuk pasien rawat inap dan perawatan satu hari sekurangkurangnya memuat: (a) identitas pasien, (b) tanggal dan waktu, (c) hasil anamnesis, (d) hasil pemeriksaan fisik dan penunjang medis,(e) diagnosis (f) rencana penatalaksanaan, $(\mathrm{g})$ pengobatan dan atau tindakan,(h) persetujuan tindakan apabila diperlukan, (i) catatan observasi klinis dan hasil pengobatan, (j) ringkasan pulang, $(\mathrm{k})$ nama dan tanda tangan dokter, dokter gigi atau tenaga kesehatan tertentu yang memberikan pelayanan kesehatan dan untuk pasien kasus gigi dilengkapi dengan odontogram klinik.

Pengetahuan seseorang adalah hasil tahu dari manusia dan ini terjadi setelah orang melakukan penginderaan terhadap suatu objek tertentu. Pengetahuan yang baik perlu didukung oleh motivasi yang tinggi dalam bekerja. Motivasi dapat memberi energi yang menggerakkan segala potensi yang ada, menciptakan keinginan yang tinggi dan luhur, serta meningkatkan kebersamaan.

Motivasi merupakan masalah kompleks dalam organisasi, karena kebutuhan dan keinginan setiap anggota organisasi berbeda satu dengan yang lainnya. Hal ini berbeda karena setiap anggota suatu organisasi adalah unik secara biologis maupun psikologis, dan berkembang atas dasar proses belajar yang berbeda pula. Secara teori berbagai definisi tentang motivasi biasanya terkandung keinginan, harapan, kebutuhan, tujuan, sasaran, dorongan. Dengan demikian suatu motif adalah keadaan kejiwaan yang mendorong, mengaktifkan dan menggerakkan dan motif itulah yang menggerakkan dan menyalurkan perilaku,

sikap dan tindak-tanduk seseorang yang selalu dikaitkan dengan pencapaian tujuan.

Berdasarkan survei pendahuluan yang dilakukan penulis terhadap rekam medis di Rumah Sakit Santa Elisabeth dengan mengambil 50 berkas rekam medis rawat inap, terlihat bahwa persentase kelengkapan pengisian rekam medis oleh dokter spesialis yang berbeda diperoleh kelengkapan pengisian sebesar 28 dokumen rekam medis (56\%) data rekam medis. Data yang diperoleh dari unit Rekam Medis tentang kelengkapan pengisian rekam medis setelah selesai pelayanan rawat inap pada bulan Oktober 2016 dari 1295 pasien terdapat 528 dokumen rekam medis (41\%) yang diisi lengkap, pada bulan November 2016 dari 1308 pasien rawat inap terdapat 618 dokumen rekam medis $(47 \%)$ rekam medis yang diisi lengkap dan bulan Desember 2016 dari 1210 pasien terdapat 593 dokumen rekam medis (49\%) dokumen yang diisi lengkap.

Berdasarkan hasil wawancara dengan Direktur Rumah Sakit Santa Elisabeth tentang kendala dalam mengatasi ketidaklengkapan penulisan rekam medis diungkapkan bahwa sangat sulit dalam memberi motivasi kepada dokter untuk mengisi rekam medis dengan lengkap. Peneliti juga melakukan wawancara kepada dokter Rumah Sakit Santa Elisabeth, berdasarkan wawancara ini dokter mengatakan ketidaklengkapan pengisian dokumen rekam medis karena kesibukan, sehingga tidak ada waktu 
mengisi rekam medis rawat inap dengan lengkap dan kurang mengetahui manfaat dari rekam medis.

Berdasarkan

beberapa

permasalahan tersebut diatas dan berkaitan dengan pentingnya kelengkapan pengisian rekam medis rumah sakit maka perlu dikaji "Pengaruh Pengetahuan dan Motivasi Kerja Dokter Spesialis terhadap Kelengkapan Pengisian Rekam Medis di Ruang Rawat Inap Rumah Sakit Santa Elisabeth".

\section{TUJUAN}

Tujuan dari penelitian ini adalah untuk menganalisis pengaruh pengetahuan (tata cara pengisian dan aspek hukum rekam medis) dan motivasi intrinsik maupun ekstrinsik (tanggung jawab, prestasi, penghargaan, gaji, kondisi kerja, hubungan antar pribadi) terhadap kelengkapan pengisian rekam medis di ruang rawat inap Rumah Sakit Santa Elisabeth.

\section{METODE}

Desain penelitian ini merupakan survei eksplanatory yang dirancang untuk menjelaskan hubungan antar variabel melalui pengujian hipotesa, bertujuan untuk mengetahui Pengaruh Pengetahuan dan Motivasi Kerja Dokter Spesialis Terhadap Pengisian Rekam Medis di Rumah Sakit Santa Elisabeth Medan. Penelitian ini dilakukan secara cross sectional, yaitu mempelajari dinamika korelasi antara variabel bebas dengan variabel tergantung yang diob servasi pada saat yang sama. Penelitian ini dilakukan di Rumah Sakit Santa Elisabeth Medan Jalan Haji Misbah no.7 Kota Medan. Waktu penelitian dilaksanakan mulai bulan Desember 2016 sampai Mei 2017.

Pada penelitian ini populasi adalah seluruh tenaga dokter spesialis yang menjadi Dokter Penanggung Jawab
Pelayanan (DPJP) rawat inap di Rumah Sakit Santa Elisabeth, yaitu 50 Dokter Spesialis terdiri dari dokter Spesialis Penyakit Dalam (9 orang), dokter Spesialis Saraf (4 orang), dokter Spesialis Jantung dan Pembuluh Darah (3 orang), dokter Spesialis Paru (3 orang), dokter Spesialis Anak (5 orang), dokter Spesialis Bedah Saraf (3 orang), dokter Spesialis Orthopedi (4 orang), dokter Spesialis Urologi (3 orang), dokter Spesialis Bedah Umum (5), dokter Spesialis Bedah Digestif (1 orang), dokter Spesialis Bedah Anak (1 orang), dokter Spesialis Bedah Onkologi (2 orang), dokter Spesialis Kebidanan dan Kandungan ( 5 orang), dokter Spesialis Telinga Hidung dan Tenggorokan (1 orang), dokter Spesialis Kulit dan Kelamin (1 orang). Sampel dalam penelitian ini menggunakan total populasi yaitu 50 orang tenaga dokter spesialis yang menjadi DPJP di Rumah Sakit Santa Elisabeth.

Penilaian pengisian kelengkapan rekam medis oleh masing- masing dokter DPJP dilihat dengan melakukan check list terhadap lembaran- lembaran rekam medis yang harus diisi oleh dokter spesialis Rumah Sakit Santa Elisabeth Medan. Rekam medis yang diambil sebagai sampel adalah satu berkas rekam medis yang diisi oleh satu DPJP dan dibedakan antara kasus medikal dengan kasus bedah.

Pada penelitian ini variabel independen adalah pengetahuan tentang rekam medis, motivasi kerja dokter spesialis dalam pengisian rekam medis dan variabel terikat adalah pengisian rekam medis rawat inap.

Setelah dikumpulkan, data akan dianalisis dengan menggunakan teknik analisa sebagai berikut:

1. Analisis univariat merupakan menggambarkan distribusi Frekuensi 
dari masing- masing variabel bebas dan variabel terikat.

2. Analisis bivariat dilakukan analisis Chi-square, pada batas kemaknaan $95 \%$ dengan perhitungan statistik $\alpha=0,05$.

3. Analisis multivariat yang digunakan adalah regresi logistik pada batas kemaknaan $95 \%$ dengan perhitungan statistik $\alpha=0,05$.

\section{HASIL DAN PEMBAHASAN}

Berdasarkan hasil penelitian hubungan pengetahuan dokter spesialis tentang rekam medis dengan pengisian rekam medis rawat inap, dapat dilihat pada tebel berikut:

\section{Tabel 1 Hubungan Pengetahuan}

Dokter Spesialis tentang

Rekam Medis dengan

Pengisian Rekam Medis

Rawat Inap di Rumah

Sakit Santa Elisabeth

Medan Tahun 2017

\begin{tabular}{|c|c|c|}
\hline \multirow[b]{2}{*}{ Pengetahuan } & \multicolumn{2}{|c|}{ Rekam Medis } \\
\hline & $\begin{array}{c}\text { Kelengkapan } \\
\text { Rendah }\end{array}$ & $\begin{array}{c}\text { Kelengkapan } \\
\text { Tinggi }\end{array}$ \\
\hline Rendah & 80,0 & 20,0 \\
\hline Tinggi & 37,5 & 62,5 \\
\hline
\end{tabular}
nilai OR sebesar 6,667 artinya dokter spesialis yang memiliki pengetahuan rendah memiliki resiko mengisi rekam medis kurang lengkap 6,667 kali lebih besar dibanding dengan dokter spesialis yang memiliki pengetahuan tinggi.

Dokter spesialis Rumah Sakit Santa Elisabeth mayoritas tidak mengetahui waktu pengisian rekam medis setelah pasien pulang, dan kegunaan kelengkapan catatan rekam medis. Sehingga dari hasil dapat diasumsikan bahwa karena kurangnya pengetahuan dokter spesialis mengenai pentingnya pengisian rekam medis dengan lengkap menyebabkan dokter spesialis tidak mengisi rekam medis dengan lengkap. Menurut Huffman rekam medis mempunyai kegunaan sebagai alat komunikasi antara dokter dengan tenaga ahli lainnya yang ikut ambil bagian di dalam memberikan pelayanan, pengobatan, perawatan kepada pasien. Sebagai dasar untuk merencanakan pengobatan/perawatan yang harus diberikan kepada seorang pasien, sebagai bukti tertulis atas segala tindakan pelayanan, perkembangan penyakit dan pengobatan selama pasien berkunjung/dirawat di rumah sakit, melindungi kepentingan hukum bagi pasien, rumah sakit maupun dokter dan tenaga kesehatan lainnya. DPJP adalah seorang dokter yang bertanggung jawab atas pengelolaan asuhan medis seorang pasien. DPJP juga bertanggung jawab terhadap kelengkapan, kejelasan, dan kebelqhran sertap ketepdan waktu dari pengembalian rekam mRdis dari pasien tersebưf. Oleh karena itu sangatlah penting

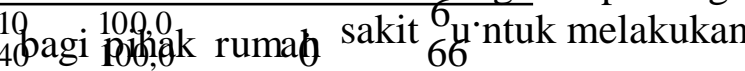
sosialisasi mengenai Standar Prosedur Operasional (SPÖ) pengisian rekam medis kepada dokter s pesialis, karena catatan rekam medis merupakan pelindung pasien dan pelindung dokter.

Beberapa kelemahan rekam medis adalah sering adanya ketidaklengkapan data seperti tidak terdapat beberapa data yang bersifat sosial-ekonomi pasien, tidak berisi penatalaksanaan pelengkap seperti penjelasan dokter dan perawat, tidak memuat kunjungan kontrol paska perawatan inap. Dampak ketidaklengkapan pengisian rekam medis rumah sakit mengundang permasalahan hukum terutama para tenaga kesehatan apabila melakukan kelalaian atau 
kesalahan yang menimbulkan kerugian bagi pasien sehingga pasien dapat menggugat tanggung jawab dokter yang membuat kesalahan atau kelalaian sesuai hukum kedokteran. Untuk itu, agar pengisian rekam medis dapat berkualitas baik maka dibutuhkan pengetahuan yang tinggi bagi para dokter spesialis.

Berdasarkan hasil penelitian hubungan motivasi dokter spesialis dengan pengisian rekam medis rawat inap, dapat dilihat pada tabel berikut:

Tabel 2 Hubungan Motivasi Dokter Spesialis dengan Pengisian Rekam Medis Rawat Inap di Rumah Sakit Santa Elisabeth Medan Tahun 2017

\begin{tabular}{|c|c|c|c|c|c|c|}
\hline \multirow{3}{*}{ Pengetahuan } & \multicolumn{4}{|c|}{ Rekam Medis } & \multirow{2}{*}{\multicolumn{2}{|c|}{ Jumlah }} \\
\hline & \multicolumn{2}{|c|}{$\begin{array}{c}\text { Kelengkapan } \\
\text { Rendah }\end{array}$} & \multicolumn{2}{|c|}{$\begin{array}{c}\text { Kelengkapan } \\
\text { Tinggi }\end{array}$} & & \\
\hline & $f$ & , & 7 & of & $f$ & \\
\hline Rendah & 16 & 69,6 & 7 & 30,4 & 23 & 100,0 \\
\hline Tinggi & 7 & 25,9 & 20 & 74,1 & 27 & 100 \\
\hline
\end{tabular}

Hasil uji Chi-Square menunjukkan bahwa nilai $\mathrm{p}=0,005<0,05$ yang artinya ada hubungan motivasi dokter spesialis tentang rekam medis dengan pengisian rekam medis rawat inap. Hasil yang didapatkan nilai OR sebesar 6,531 artinya dokter spesialis yang memiliki motivasi rendah memiliki resiko mengisi rekam medis kurang lengkap 6,531 kali lebih besar dibanding dengan dokter spesialis yang memiliki motivasi tinggi.

Hasil penelitian ini sejalan dengan penelitian yang dilakukan oleh Supriyati 2010 ada korelasi dan signifikan antara pengetahuan dan motivasi perawat dengan kelengkapan pengisian resume keperawatan di instalasi rawat inap reguler RSUD Dr. Moewardi Surakarta.

$$
\text { Peningkatan motivasi dapat }
$$
dilakukan dengan memberikan sanksi kepada dokter yang tidak mengisi rekam medis dengan lengkap dan memberikan reward kepada dokter yang catatan rekam medisnya lengkap karena motivasi merupakan daya pendorong yang mengakibatkan seseorang anggota organisasi mau dan rela untuk menyerahkan kemampuan dalam bentuk keahlian atau keterampilan, tenaga dan waktunya untuk menyelenggarakan berbagai kegiatan yang menjadi tanggungjawabnya dan menunaikan kewajibannya dalam rangka pencapaian tujuan dan berbagai sasaran organisasi yang telah ditentukan sebelumnya. Dokter spesialis yang memiliki motivasi untuk mencapai prestasi yang baik memungkinkan meningkatkan kinerja pelayanan kepada pasien dan masyarakat yang membutuhkan pelayanan rekam medis.

$p$ ORnalisis multivariat pada penelitian ini adalah uji regresi logistik gondas.(bsultiple logistic reg ression).

Tabel 3. Hasil Analisis yang Memenuhi Astmmsi Multivariat (Kandidat)

\begin{tabular}{lc}
\hline Variabel & Sig $(\boldsymbol{p}$-value $)$ \\
\hline Pengetahuan & $0,030^{*}$ \\
Motivasi & $0,005^{*}$ \\
\hline
\end{tabular}

Keterangan :* variabel yang memenuhi syarat

Berdasarkan hasil uji bivariat, variabel yang dijadikan model pada uji logistik berganda adalah variabel pengetahuan memiliki nilai $p$ sebesar 0,030 dan variabel motivasi memiliki nilai p sebesar 0,005. Dengan demikian kedua variabel ini memenuhi syarat untuk dimasukkan dalam model prediksi regresi logistik ganda.

\section{Tabel 4. Model Summary}

\begin{tabular}{rrrrr}
\hline Step & $\begin{array}{l}-2 \text { Log } \\
\text { likelihood }\end{array}$ & $\begin{array}{l}\text { Cox } \\
\text { Snell } \\
\text { Square }\end{array}$ & $\begin{array}{c}\text { \& } \\
\text { R }\end{array}$ & $\begin{array}{r}\text { Nagelkerke } \\
\text { R S quare }\end{array}$ \\
\hline 1 & 54.090 & .258 & .344 \\
\hline
\end{tabular}

Dari tabel di atas dapat dilihat nilai Nagelkerke $R$ Square pada penelitian ini 
sebesar 0,344 artinya kemampuan variabel independen dalam menjelaskan variabel dependen adalah sebesar 0,344 atau $34,4 \%$ dan terdapat $100 \%-34,4 \%=$ $65,6 \%$ faktor lain di luar model yang menjelaskan variabel dependen. Faktorfaktor lain tersebut antara lain faktor waktu, beban kerja, usia, lama kerja, tidak adanya kebijakan, panduan dan SPO pengisian rekam medis, kesadaran dokter untuk mengisi rekam medis kurang, tidak adanya data ketidaklengkapan rekam medis, sistem monitoring dan evaluasi rekam medis tidak efektif.

Tabel 5. Classification Result

\begin{tabular}{|c|c|c|c|c|}
\hline & \multirow{2}{*}{\multicolumn{2}{|c|}{ Observed }} & \multicolumn{2}{|c|}{$\begin{array}{r}\text { Predicted } \\
\text { Rekam I }\end{array}$} \\
\hline & & & $\begin{array}{l}\text { kelengk } \\
\text { apan } \\
\text { rendah }\end{array}$ & $\begin{array}{c}\text { kelengkapan } \\
\text { tinggi }\end{array}$ \\
\hline \multirow{5}{*}{$\begin{array}{l}\text { Step } \\
1\end{array}$} & Rekam & kelengka & & \\
\hline & Medis & $\begin{array}{l}\text { pan } \\
\text { rendah }\end{array}$ & 18 & 5 \\
\hline & & $\begin{array}{l}\text { kelengka } \\
\text { pan } \\
\text { tinggi }\end{array}$ & 9 & 18 \\
\hline & Overall & & & \\
\hline & Percent & & & \\
\hline
\end{tabular}

Berdasarkan tabel di atas jumlah responden yang mengisi rekam medis kelengkapan tinggi sebanyak $9+18=27$ orang. Yang benar-benar pengisian kelengkapan tinggi sebanyak 18 orang. Jumlah responden yang mengisi rekam medis kelengkapan rendah $18+5=23$ orang. Yang benar-benar pengisian kelengkapan rendah sebanyak 18 orang dan yang seharusnya mengisi rekam medis kelengkapan kurang namun mengisinya dengan kelengkapan tinggi sebanyak 9 orang. Nilai Overall Percentage sebesar $(18+18) / 50=0,72=72 \%$ yang berarti ketepatan model penelitian ini adalah sebesar $72,0 \%$.

Variabel yang terpilih dalam model akhir regresi logistik ganda dapat dilihat pada Tabel 6 berikut :
Tabel 6. Hasil Akhir Uji Regresi Logistik Berganda

\begin{tabular}{lccc}
\hline \multicolumn{1}{c}{ Variabel } & B & Sig. & $\operatorname{Exp}(\mathbf{B})$ \\
\hline Pengetahuan & 1,922 & 0,039 & 6,837 \\
Motivasi & 1,892 & 0,005 & 6,635 \\
Konstanta & $-2,401$ & - & - \\
\hline
\end{tabular}

Berdasarkan hasil yang diperoleh bahwa pengetahuan dokter spesialis berpengaruh terhadap pengisian rekam medis rawat inap dengan nilai $\mathrm{p}=0,039$. pengetahuan memiliki nilai $\operatorname{Exp}(\mathrm{B})=$ 6,837 artinya dokter spesialis yang memiliki pengetahuan rendah lebih beresiko mengisi rekam medis kelengkapan rendah sebesar 6,837 kali lipat dibandingkan dengan dokter spesialis yang memiliki pengetahuan tinggi tentang ercukam medis. Nilai $\mathrm{B}=$ Logaritma Natural ${ }^{\text {age }}$ dari $6,837=1,922$. Oleh karena itu nilai $\mathrm{B}$ bernilai positif maka pengetahuan 78.mempunyai pengaruh positif dengan pengisian rekam medis.

66.7 Ada pengaruh motivasi dokter spesialis terhadap pengisian rekam medis 72. Pawat inap dengan nilai $\mathrm{p}=0,005$. Motivasi memiliki nilai $\operatorname{Exp}(B)=6,635$ artinya dokter spesialis yang memiliki motivasi rendah lebih beresiko mengisi rekam medis kelengkapan rendah sebesar 6,635 kali lipat dibanding dengan dokter spesialis yang memiliki motivasi tinggi. Nilai B = Logaritma Natural dari 6,635= 1,892. Oleh karena itu nilai $\mathrm{B}$ bernilai positif maka motivasi mempunyai pengaruh positif dengan pengisian rekam medis.

Berdasarkan nilai-nilai B pada perhitungan di atas, maka model persamaan yang dibentuk adalah sebagai berikut:

Probabilitas $=$

$$
p(y)=\frac{\exp (-2,401+1,922 X 1+1,892 X 2}{1+\exp (-2,401+1,922 X 1+1,892 \times 2}
$$


Probabilitas atau predicted $=$

$$
\begin{aligned}
& \frac{\exp (-2,401+1,922 \times 1+1,892 \times 1}{1+\exp (-2,401+1,922 \times 1+1,892 \times 1} \\
& =0,804
\end{aligned}
$$

Artinya apabila dokter spesialis dengan pengetahuan rendah dan motivasi rendah kemungkinan untuk mengisi rekam medis dengan kelengkapan rendah sebesar $80,4 \%$.

Hasil penelitian ini sejalan dengan penelitian yang dilakukan oleh Maryati Tahun 2014 menyatakan bahwa karakteristik dokter yang paling berpengaruh terhadap kelengkapan pengisian Lembar Ringkasan Keluar (Resume Dokter) adalah pengetahuan dokter tentang rekam medis dengan signifikansi 0,008, kemudian yang berpengaruh kedua yaitu masa kerja dokter dengan signifikansi 0,018, dan yang berpengaruh urutan ketiga yaitu pendidikan dokter dengan signifikansi 0,047 .

Kelengkapan rekam medis merupakan salah satu kewajiban yang harus dilakukan oleh seorang dokter, alat komunikasi antara dokter dan tenaga kesehatan lainnya yang ikut andil dalam proses pemberian pelayanan serta dapat dijadikan sebagai bahan yang berguna untuk analisa, penelitian dan evaluasi terhadap kualitas pelayanan yang telah diberikan kepada pasien. Rekam medis yang tidak lengkap akan berdampak terhadap kegunaan rekam medis seperti administrasi, legal, keuangan, pendidikan, penelitian dan dokumentasi. Selain itu, ketidaklengkapan rekam medis akan menghasilkan informasi yang tidak tepat dan bersifat legal. Maka dari itu, setiap tenaga kesehatan yang memberikan pelayanan terhadap pasien harus mengisi rekam medis secara lengkap untuk menghindari hal-hal yang tidak diinginkan.
Seorang dokter spesialis harus mampu mengisi rekam medis dengan lengkap, jelas, akurat dan dapat dipahami oleh orang lain. Namun, dalam pelaksanaannya pengisian rekam medis oleh dokter spesialis Rumah Sakit Santa Elisabeth masih mengalami permasalahan seperti tidak lengkapnya pengisian rekam medis. Dari penelitian ini didapatkan pengisian lembaran-lembaran rekam medis medikal assesmen awal rawat inap yang paling banyak tidak lengkap adalah rencana sebanyak 16 orang (64\%) dan diagnosa banding sebanyak 15 orang (60\%), riwayat pemakaian obat 6 responden (24\%), riwayat penyakit terdahulu 5 responden (20\%). Pengisian lembar resume medis medikal yang diisi tidak lengkap adalah kontrol ulang sebanyak 15 responden $(60 \%)$, tindakan sebanyak 10 responden $(40 \%)$, kondisi saat pulang sebanyak 13 orang (52\%), ringkasan pasien selama dirawat sebanyak 6 responden (24\%), pemeriksaan penunjang, identitas dokter dan tanggal sebesar $20 \%$.

\section{KESIMPULAN}

1. Pengetahuan dokter spesialis berpengaruh terhadap pengisian rekam medis rawat inap Rumah Sakit Santa Elisabeth Medan. Hal ini ditunjukkan dengan nilai $\mathrm{p}=0,030$, nilai exp (B) 6,837 artinya dokter spesialis yang mempunyai pengetahuan rendah memiliki peluang untuk mengisi rekam medis tidak lengkap sebesar 6,837 kali dibanding dengan yang berpengetahuan tinggi

2. Motivasi kerja dokter spesialis berpengaruh terhadap pengisian rekam medis rawat inap Rumah Sakit Santa Elisabeth Medan. Hal ini ditunjukkan dengan nilai $\mathrm{p}=0,005$, nilai $\exp (\mathrm{B})$ 6,635 artinya dokter spesialis yang mempunyai motivasi rendah memiliki 
peluang untuk mengisi rekam medis tidak lengkap sebesar 6,635 kali dibanding dengan yang memiliki motivasi tinggi.

3. Terdapat pengaruh yang positif dan signifikan antara pengetahuan dan motivasi kerja dokter spesialis terhadap pengisian rekam medis rawat inap Rumah Sakit Santa Elisabeth Medan

\section{DAFTAR PUSTAKA}

1. Departemen Kesehatan RI. Peraturan Menteri Kesehatan Republik Indonesia no. 129 tentang Standar Pelayanan Minimal Rumah Sakit. Jakarta: Dicetak oleh Kementerian Kesehatan Republik Indonesia; 2008.

2. Jusuf H. Etika Kedokteran dan Hukum Kesehatan. Jakarta: Penerbit Buku Kedokteran, EGC; 2014.

3. Djoko W. Manajemen Mutu Pelayanan Kesehatan Teori, Strategi dan Aplikasi. Surabaya: Penerbit Airlangga University Press; 2000.

4. Gemala R.H. Pedoman Manajemen Kesehatan di Sarana Pelayanan Kesehatan. Jakarta: Penerbit Universitas Indonesia; 2008.

5. Departemen Kesehatan RI. Peraturan Menteri Kesehatan nomor 269, Tentang Rekam Medis. Jakarta: Dicetak oleh Kementerian Kesehatan Indonesia; 2008

6. Chandrawilla W. Hukum Kedokteran, Bandung: Mandar Madju; 2001.

7. Soekidjo N. Pengembangan Sumber Daya Manusia. Jakarta: Penerbit Rhineka Cipta; 2010.

8. Wahyu T. Analisis Ketidaklengkapan Pengisian Berkas Rekam Medis Di Rumah Sakit PKU Muhammadiyah [Tesis].Yogjakarta; 2010.

9. Departemen Kesehatan RI, Undangundang Republik Indonesia No. 44. Tentang Rumah sakit, Jakarta, 2009.
10. Departemen Kesehatan RI, Peraturan Menteri Kesehatan Republik Indonesia Nomor 340, Klasifikasi Rumah sakit. Jakarta: Diterbitkan oleh Kementerian Kesehatan Republik Indonesia; 2010.

11. Gede AAM. Manajemen Kesehatan edisi 2, Jakarta: Penerbit EGC;2004.

12. Ery R. Statistik Rumah Sakit untuk Pengambilan Keputusan, edisi Pertama, Yogyakarta: Graha Ilmu; 2010.

13. Gemala RH. Pedoman Manajemen Kesehatan Di Sarana Pelayanan

Kesehatan. Jakarta: Penerbit Universitas Indonesia; 2008.

14. PORMIKI, Seminar Nasional dalam Kongres \& Rakernas Pormiki, Jakarta: PORMKI, 2003.

15. Departemen Kesehatan RI, Peraturan Menteri Kesehatan Republik Indonesia Nomor 71 Tentang Pelayanan Kesehatan Pada Jaminan Kesehatan Nasional. Jakarta: 2013.

16. Stephen PR. Perilaku Organisasi. Jakarta: Penerbit Salemba Empat; 2008.

17. Soekidjo N. Metodologi Penelitian Kesehatan. Jakarta: Penerbit Rhineka Cipta; 2012.

18. Sugiyono, Metode Penelitian Kuantitatif dan Kualitatif. Bandung: Penerbit. PT.Alfaberta.; 2011.

19. Edna KH. Health information Management, Physician Record Company, Berwyn, Illinois, 1994.

20. Maryati. Hubungan Antara Karakteristik Dokter dengan Dokter dengan Kelengkapan Pengisian Lembar Ringkasan Keluar. 2014

21. Nursalam. Motivasi dan Kepuasan Kerja, Surabaya: Penerbit Salemba Medika; 2008. 